\title{
IMPLEMENTASI PEMANFAATAN LATIHAN TERBIMBING DAN PEMBELAJARAN MENULIS NASKAH DRAMA BERBASIS EKOLOGI DAS CITARUM
}

\author{
Aditya Permana1, N. Mahmud Firdaus², dan Dida Firmansyah ${ }^{3}$ Indra Permana ${ }^{4}$ \\ 1,2, 3,4 IKIP Siliwangi \\ 1 adit0905@ikipsiliwangi.ac.id ${ }^{2}$ firdaus@ikipsiliwangi.ac.id ${ }^{3}$ dida- \\ firmansyah@ikipsiliwangi.ac.id, indrapermana@ikipsiliwangi.ac.id
}

\begin{abstract}
ABSTRAK
Implementasi Pemanfaatan Latihan Terbimbing dan Pembelajaran Menulis Naskah Drama Berbasis Ekologi DAS Citarum. Daerah aliran sungai (DAS) Citarum menjadi salah satu perangkat utama dalam proses pembelajaran dengan tujuan untuk membangun kesadaran masyarakat terhadap upaya pemeliharaan kualitas lingkungan yang berada di DAS Citarum. Proses upaya penyadaran dilakukan dengan berbagai pendekatan yang saling berkaitan terutama dalam membentuk karakter utama masyarakat dalam pemanfaatan ekologi DAS Citarum secara bijaksana dan produktif. Pembelajaran bahasa melalui drama, diharapkan dapat menjadi salah satu upaya untuk menunjang pembelajaran terhadap masyarakat, dengan metode yang tidak terlalu kaku, namun efektif. Drama sebagai salah satu bentuk sastra populer diharapkan dapat membangun kesadaran masyarakat dengan komunikasi yang lebih menarik. Pelatihan terbimbing merupakan metode pendidikan sastra yang lebih fleksibel terhadap kualitas pembelajaran bahasa dan sastra. Landasan utama dalam program pengabdian adalah hasil pengabdian yang dilakukan oleh A. Permana dan R. Hidayat (2018) yang berkaitan dengan latihan terbimbing dan pembelajaran menulis naskah drama. Metode pengabdian yang dilakukan adalah dengan program pelatihan terbimbing dan demonstrasi drama dengan memanfaatkan ekologi DAS Citarum
\end{abstract}

Kata Kunci : Latihan terbimbing; pembelajaran latihan terbimbing; naskah drama; ekologi das citarum

\begin{abstract}
Implementation of the Utilization of Guided Exercises and Learning Writing for Drama Script Based on Citarum River Basin Ecology. The Citarum watershed (DAS) has become one of the main tools in the learning process with the aim of building public awareness of efforts to preserve environmental quality in the Citarum watershed. The awareness raising process is carried out with various interrelated approaches, especially in shaping the main character of the community in the wise and productive use of the Citarum watershed ecology. Language learning through drama, is expected to be one of the efforts to support learning of the community, with methods that are not too rigid, but effective. Drama as one of the popular forms of literature is expected to build public awareness with more interesting communication. Guided training is a method of literary education that is more flexible to the quality of language and literature learning. The main foundation in the service program is the results of the service performed by A. Permana and R. Hidayat (2018) relating to guided training and learning to write drama scripts. The dedication method used is guided training programs and drama demonstrations using the Citarum watershed ecology
\end{abstract}

Keywords: Guided training; guided training learning; play script; das citarum ecology

\section{A. PENDAHULUAN}

Perkembangan konservasi DAS Citarum menjadi salah satu prioritas utama dalam proses pelestarian lingkungan berdasarkan atas Peraturan Presiden Nomor 15/2018 tentang Percepatan Pengendalian Pencemaran dan Kerusakan Daerah Aliran Sungai 
Citarum. Upaya pelesatarian telah dilakukan dengan beragam cara, termasuk diantaranya adalah tindakan tegas dengan melibatkan aparat penegak hukum seperti kepolisian dan TNI. Namun demikian, selain upaya hukum, juga perlu dilakukan upaya lain diantaranya adalah dengan melibatkan perguruan tinggi dan satuan-satuan pendidikan masyarakat untuk lebih mengembangkan kualitas program pengendalian pencemaran dan kerusakan DAS Citarum. Hal ini karena dalam beberapa latar belakang pencemaran DAS Citarum selain melibatkan perusahan tekstil dan industri lainya, juga dipengaruhi kesadaran masyarakat, terutama dalam pencemaran limbah domestik rumah tangga. Untuk itu perlu membangun kesadaran masyarakat dalam rangka memelihara DAS Citarum di masa yang akan datang, terutama kepada generasi muda bagi masyarakat yang berada di DAS Aliran Sungai Citarum.

Untuk itu dilakukan beragam upaya pendidikan untuk mendukung program tersebut, diantaranya adalah dengan mengadakan beragam kegiatan kampanye pemeliharaan DAS Citarum. Karena kampanye yang lebih masif dan menyentuh seluruh lapisan masyarakat akan memberikan dampak yang lebih signifikan terhadap upaya pelestarian DAS Citarum. Kesadaran masyarakat untuk memanfaatkan DAS Citarum secara tepat sekaligus melestarikannya membutuhkan tindakan yang berkelanjutan dan komprehensif.

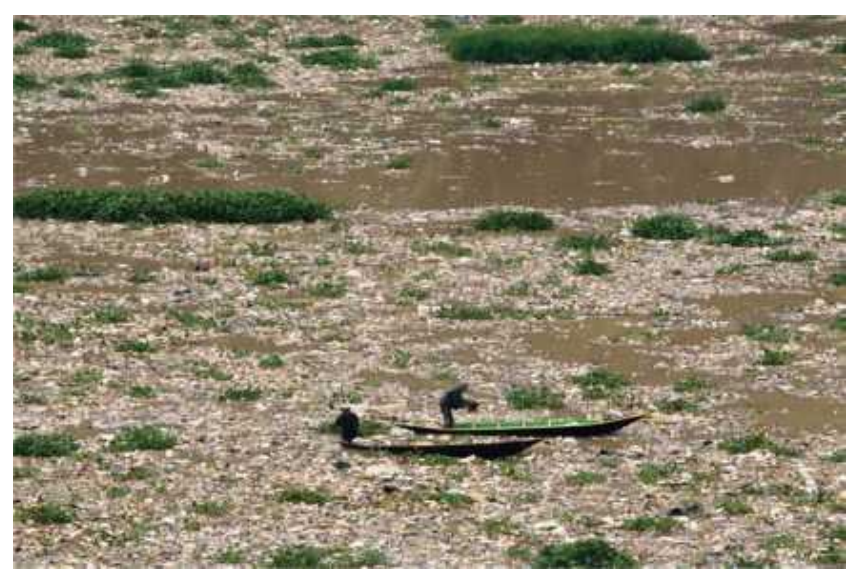

Gambar 1. Kondisi Pencemaran di DAS Citarum

(Sumber : National Geographic Indonesia,

http://nationalgeographic.grid.id/read/13278579/mengikat-nasib- pada-nadicitarum?page=all)

\section{B. LANDASAN TEORI}

\section{Kawasan Ciseupan Kelurahan Cibeber Kecamatan Cimahi Selatan Kota Cimahi}

Lokasi utama untuk kegiatan pengabdian ini adalah di Taman Bacaan Masyarakat (TBM) Bening Saguling Foundation yang berlokasi di Jl.SDN Cianjur, Babakan, 
Cihampelas, Kabupaten Bandung Barat, Jawa Barat 40562. Di belakang lokasi ini langsung menghadap Bendungan Saguling yang juga merupakan bagian dari Sungai Citarum.

Permasalahan utama yang dihadapi di lapangan adalah terkait dengan rendahnya minat masyarakat untuk membaca, walaupun kunjungan untuk TBM bersifat gratis dan terbuka untuk umum. Namun demikian, masyarakat dan anak-anak lebih sering memanfaatkan lokasi TBM sebagai pusat kegiatan pengajian maupun permainan anakanak di sore hari. Sehingga diperlukan diversifikasi kegiatan untuk mendukung peningkatan minat masyarakat untuk berkunjung dengan kegiatan yang lebih informatif dan produktif. Saat ini TBM Bening Saguling memiliki koleksi sebanyak 450 buah buku. Namun keberadaan TBM belum dimanfaatkan secara optimal. Sehingga berbagai sumbangan yang diberikan oleh beberapa pihak seperti perguruan tinggi maupun sumbangan pribadi belum dapat dimanfaatkan secara baik.

Masalah lainnya adalah jumlah koleksi yang ada dinilai masih kurang relevan dengan berbagai konteks pemeliharaan DAS Citarum. Sehingga kurang memberikan pemahaman tentang kondisi lingkungan yang berada di sekitar DAS Citarum. Selain itu, relevansi buku dengan kebutuhan masyarakat juga dinilai kurang, karena koleksi yang ada sebagian besar merupakan buku bekas, dan kurangnya fasiliator yang dapat menjelaskan pemanfaatan buku dinilai masih sangat kurang. Oleh karena itu, membutuhkan dukungan dan program yang lebih menarik untuk mengundang partisipasi masyarakat.
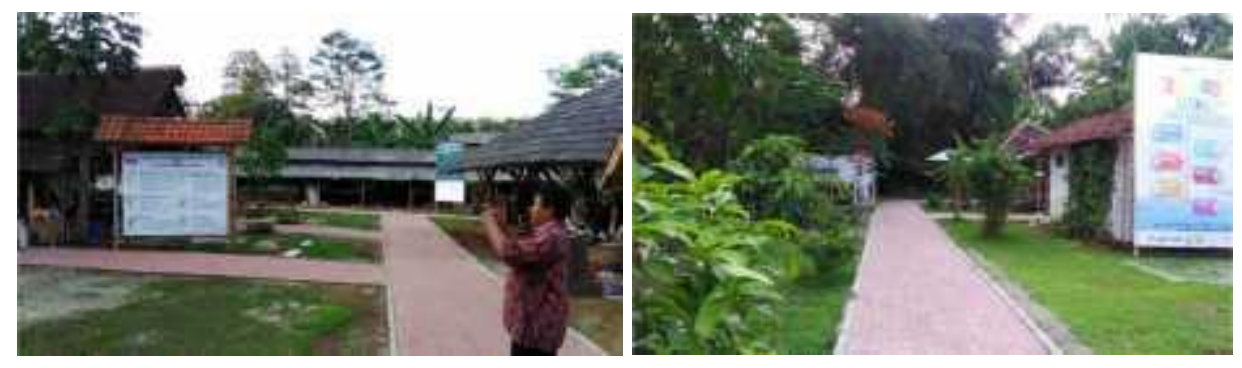

Gambar 2. Lokasi Utama Saguling Bening Foundation di Desa Cihampelas, Kec.Cihampelas, Kab. Bandung Barat

(Sumber : dokumentasi tim pelaksana pengabdian)

Selain itu, kondisi mitra yang ada juga kadang kurang mendapatkan dukungan masyarakat, hal ini karena rendahnya tingkat pendidikan masyarakat, walaupun berdekatan dengan sekolah formal namun demikian, karena pendidikan dinilai kurang 
memberikan manfaat langsung untuk kehidupan ekonomi, maka dianggap sebagai kepentingan yang tidak terlalu urgen. Hal ini membuat beberapa program pendidikan hanya mendapatkan partisipasi yang rendah dari masyarakat.

Namun demikian, untuk kegiatan pengajian rutin, berhasil menarik minat masyarakat, meskipun hanya berasal dari golongan usia tertentu dan belum dapat menarik perhatian dari kelompok masyaraka yang lebih muda. Mereka lebih tertarik untuk mulung sampah atau menjadi buruh pabrik/ buruh pertanian. Pemuda juga lebih banyak tertarik pada kegiatan- kegiatan populer yang terkadang kurang memberikan manfaat terhadap pembangunan manusia maupun pengembangan perekonomian kreatif, sehingga peran serta pemuda menunjukkan penurunan. Sesuai dengan penjelasan dari Ketua Bening Saguling Foundation yang menjelaskan tentang peran pemuda dalam upaya pembangunan kehidupan perekonomian yang ada di lingkungan sekitar Bening Saguling Foundation.

\section{Menulis Naskah Drama}

a. Pengertian Menulis

Menurut Ahmad Rofi'uddin dan Darmiyati Zuhdi (1999: 159), keterampilan menulis merupakan suatu keterampilan menuangkan pikiran, gagasan, pendapat tentang sesuatu, tanggapan terhadap suatu pernyataan keinginan, atau pengungkapan perasaan dengan menggunakan bahas tulis. Keterampilan menulis merupakan salah satu jenis keterampilan berbahasa yang harus dikuasai siswa. Banyak ahli telah mengemukakan pengertian menulis. Menurut pendapat Abbas (2006:125), keterampilan menulis adalah kemampuan mengungkapkan gagasan, pendapat, dan perasaan kepada pihak lain dengan melalui bahasa tulis. Ketepatan pengungkapan gagasan harus didukung dengan ketepatan bahasa yang digunakan, kosakata dan gramatikal dan penggunaan ejaan.

b. Tujuan Menulis

Menulis adalah menyampaikan pikiran berupa sebuah tulisan. Tarigan (2008: 24) mengemukakan bahwa setiap jenis tulisan mengandung beberapa tujuan, tetapi tujuan itu sangat beraneka ragam, bagi penulis yang belum berpengalaman ada baiknya memperhatikan kategori sebagai berikut :

1) Memberitahukan atau mengajar

2) Menyakinkan atau mendesak

3) Menghibur atau menyenangkan

4) Mengutarakan, mengekspresikan perasaan dan emosi yang berapi-api 
Hugo Hartig dalam Tarigan (2008: 25) merangkum tujuan menulis sebagai berikut :

1) Assignment purpose (tujuan penugasan).

Tujuan penugasan ini sebenarnya tidak memiliki tujuan sama sekali. Penulis menulis sesuatu karena ditugaskan, bukan atas dasar kemauan sendiri.

2) Altruistik purpose (tujuan altruistik)

Penulis bertujuan untuk menyenangkan para pembaca, menghindarkan kedukaan para pembaca, ingin menolong para pembaca memahami, menghargai perasaan dan penalarannya, ingin membuat hidup para pembaca lebih mudah dan lebih menyenangkan dengan karyanya itu.

3) Persuasive purpose (tujuan persuasif)

Tulisan yang bertujuan meyakinkan para pembaca akan kebenaran gagasan yang diutarakan. Informational purpose (tujuan informasional, tujuan penerangan) Tulisan yang bertujuan memberikan informasi atau keterangan kepada pembaca.

4) Self-expressive purpose (tujuan pernyataan diri)

Tulisan yang bertujuan memperkenalkan atau menyatakan diri pengarang kepada pembaca.

5) Creative purpose (tujuan kreatif)

Tujuan ini erat berhubungan dengan tujuan pernyataan diri. Tetapi "keinginan kreatif" di sini melebihi pernyataan diri, dan melibatkan dirinya dengan keinginan mencapai nora artistik, atau seni yang ideal, seni idaman.

6) Problem-solving purpose (tujuan pemecahan masalah)

Tujuan menulis yakni penulis ingin menyampaikan amanat, pesan atau sekedar memberikan informasi saja tentang sesuatu. Dalam hal ini, ada kalanya penulis menyampaikan sesuatu gagasan dan mengembangkan melalui seluruh tulisannya.

\section{c. Naskah Drama}

Menurut KBBI naskah adalah karangan yang masih ditulis dengan tangan yang belum diterbitkan. Suryono (2011) menjelaskan bahwa drama adalah suatu aksi atau perbuatan (bahasa yunani). Sedangkan dramatik adalah jenis karangan yang dipertunjukkan dalam suatu tingkah laku, mimik dan perbuatan. Sandiwara adalah sebutan lain dari drama dimana sandi adalah rahasia dan wara adalah pelajaran. Orang yang memainkan drama disebut aktor atau lakon. Dari beberapa pengertian diatas dapat disimpulkan bahwa naskah drama adalah sebuah tulisan yang bercerita tentang kisah yang dituangkan dalam sebuah pertunjukan. 


\section{METODE PELAKSANAAN}

\section{Metode Pelaksanaan}

Metode pelaksanaan yang akan dilakukan dalam pengabdian ini adalah :

1. Pelatihan kepada pengelola dan komunitas masyarakat yang menjadi anggota Taman Bacaan Masyarakat Bening Saguling, untuk memberikan kesempatan kepada masyarakat untuk jauh lebih memahami tentang esensi keberaan Taman Bacaan Masyarakat dan implikasinya terhadap masyarakat dengan menggunakan beragam fasilitas TBM yang ada di dalamnya.

2. Melaksanakan pembelajaran pembuatan naskah drama, dengan tema Ekologi DAS Citarum maupun kehidupan sosial masyarakat sekitar DAS Citarum. Untuk membangun kesadaran dan kemampuan untuk memahami urgensi pelestarian DAS Citarum.

3. Mengembangkan keterampilan menulis drama sebagai salah satu alternatif dalam memfasilitasi minat dan bakat anggota TBM dalam upaya kampanye pelestarian Ekologi DAS Citarum

Adapaun metode pelaksanaan kegiatan secara lengkap adalah sebagai berikut.

1. Survei awal

Survei awal dilaksanakan melalui pedoman observasi dan studi dokumentasi untuk melihat gambaran masyarakat dan permasalahan di TBM Bening Saguling sebelum TBM Bening Saguling tersebut dijadikan sebagai masyarakat sasaran pada program PKMS ini.

\section{Identifikasi masalah}

Identifikasi masalah yang dilakukan dalam rangka kegiatan PKMS ini secara umum berdasarkan hasil survei, potret, dan profil TBM Bening Saguling sasaran yang telah digambarkan pada sub-bab sebelumnya, dimana TBM Bening Saguling sasaran dilihat dari sebaran mata pencaharian sebagian besar bekerja sebagai buruh, wiraswasta, pedagang, pengrajin, dan tidak bekerja.

3. Analisis kebutuhan

Analisis kebutuhan berdasarkan survei melalui observasi, studi dokumentasi, dan wawancara kepada masyarakat yaitu kurangnya pemahaman, kesadaran, dan keterampilan masyarakat dalam pengolahan sampah dan pelestarian lingkungan sehingga terjadi alih fungsi kawasan resapan air menjadi tempat pembuangan sampah liar. 
4. Penetapan khalayak sasaran

Penetapan TBM Bening Saguling dilakukan berdasarkan hasil survei dan analisis kebutuhan TBM Bening Saguling, sehingga ditetapkan kelurahan Cihampelas.

5. Penyusunan program

Penyusunan program kegiatan PKMS ini dilakukan dalam rapat rutin yang diselenggarakan setiap minggunya yang dihadiri oleh para stakeholder program PKMS.

6. Pelaksanaan Program

Pelaksanaan program mengacu pada jadwal kegiatan dan indikator keberhasilan program yang telah disusun.

7. Strategi pembinaan khalayak sasaran

Strategi yang digunakan dalam mewujudakan luaran-luaran yang dikemukakan di poin sebelumnya yaitu melalui sosialisasi, kerjasama dengan lembaga-lembaga pemerintah kelurahan, tokoh masyarakat, lembaga-lembaga dalam bidang lingkungan hidup, dilakukan pendampingan/workshop secara berkala kepada anak asuh TBM Bening Saguling.

8. Monitoring dan evaluasi berdasarkan indikator keberhasilan program

Monitoring dan evaluasi dilakukan berdasarkan indikator keberhasilan program yang telah disusun.

9. Penyusunan laporan

Penyusunan laporan hasil kegiatan PKMS mengikuti rancangan jadwal yang diagendakan oleh tim sesuai panduan PKMS.

10. Penetapan khalayak sasaran

Penetapan masyarakat dilakukan berdasarkan hasil survei dan analisis kebutuhan masyarakat, sehingga ditetapkan kelurahan Cibeber Kecamatan Cimahi Selatan Kota Cimahi sebagai masyarakat sasaran pada program PKMS ini.

11. Penyusunan program

Penyusunan program kegiatan PKMS ini dilakukan dalam rapat rutin yang diselenggarakan setiap minggunya yang dihadiri oleh para stakeholder program PKMS.

12. Perumusan dan pengukuran indikator keberhasilan

Penyusunan dan pengukuran indikator keberhasilan program kegiatan PKMS ini dilakukan dalam rapat rutin yang diselenggarakan setiap minggunya yang dihadiri oleh para ketua dan anggota program PKMS. 
13. Pelaksanaan Program

Pelaksanaan program mengacu pada jadwal kegiatan dan indikator keberhasilan program yang telah disusun.

14. Strategi pembinaan khalayak sasaran

Strategi yang digunakan dalam mewujudakan luaran-luaran yang dikemukakan di poin sebelumnya yaitu melalui sosialisasi, kerjasama dengan lembaga-lembaga pemerintah kelurahan, tokoh masyarakat, lembaga-lembaga dalam bidang lingkungan hidup, dilakukan pendampingan/workshop secara berkala kepada masyarakat sasaran.

15. Monitoring dan evaluasi berdasarkan indikator keberhasilan program

Monitoring dan evaluasi dilakukan berdasarkan indikator keberhasilan program yang telah disusun.

16. Penyusunan laporan

Penyusunan laporan hasil kegiatan PKMS mengikuti rancangan jadwal yang diagendakan oleh tim sesuai panduan PKMS.

\section{HASIL DAN PEMBAHASAN}

\section{Hasil}

Kegiatan pengabdian masyarakat ini dilaksanakan di Taman Bacaan Masyarakat (TBM) Bening Saguling Foundation yang berlokasi di Jl.SDN Cianjur, Babakan, Cihampelas. Kegiatan pengabdian ini bertujuan untuk meningkatan pemahaman, keterampilan, dan kesadaran dalam prilaku hidup bersih dan sehat melalui pembelajaran menulis naskah drama.

Kegiatan pengabdian berupa pelatihan secara berkala kepada anak-anak asuh Bening Saguling Foundation tersebut dilaksankan selama empat bulan yaitu dari bulan April Juli 2019 denga melibatkan tim pengabdian dan bekerjasama dengan para mitra yang ada di kelurahan Cihampelas seperti aparat pemerintahan kelurahan Cihampelas dan lembaga-lembaga di kelurahan tersebut seperti PKK dan karang taruna.

Keberhasilan kegiatan pengabdian kepada masyarakat ini diukur sesuai dengan indikator-indikator yang telah disusun oleh tim pengabdian masyarakat. Adapun hasil dari pengabdian kepada masyarakat ini adalah sebagai berikut : 
Tabel 1. Hasil Pengabdian Kepada Masyarakat di Kelurahan Cibeber Kec. Cimahi Selatan Kota Cimahi

\begin{tabular}{llll}
\hline \multirow{2}{*}{ INDIKATOR } & \multicolumn{1}{c}{ SEBELUM } & \multicolumn{1}{c}{$\begin{array}{c}\text { KEGIATAN } \\
\text { PENGABDIAN }\end{array}$} \\
\hline Perubahan & Kurangnya & Pelatihan Menulis & PETELAH \\
prilaku & pemahaman & Naskah Drama & (Instrumen: Wawancara) \\
& masyarakat & dengan latihan & Hasil: Memahami keterampilan menulis \\
& (anak-anak asuh) & terbimbing & naskah. \\
tentang menjaga & & Sikap: \\
lingkungan & & (Instrumen Observasi/Dokumentasi) \\
& sekitar. Serta & & Hasil: Terwujudnya kesadaran masyarakat \\
& kurangnya & & dalam mewujudkan kawasan BESTARI untuk \\
& kepedulian & & menciptakan Citarum Harum. \\
& masyarakat & & Keterampilan: \\
terhadap & & (Instrumen Observasi/Dokumentasi) \\
& lingkungan. & & Hasil: Memiliki keterampilan dalam \\
& & menulisnaskah drama untuk \\
& & diiplementasikan dalam kehidupan sehari- \\
& & hari \\
\hline
\end{tabular}

\section{Pembahasan}

Dilihat dari hasil pengabdian masyarakat pada tabel 1 dapat diartikan bahwa kegiatan pengabdian kepada masyarakat tersebut memberikan dampak yang positif dalam meningkatkan pemahaman, keterampilan, dan kesadaran dalam menjaga kebersihan lingkungan untuk mewujudkan kawasan Citarum Harum. Adapun keberhasilan kegiatan pengabdian kepada masyarakat ini dapat dilihat pada gambar di bawah ini.

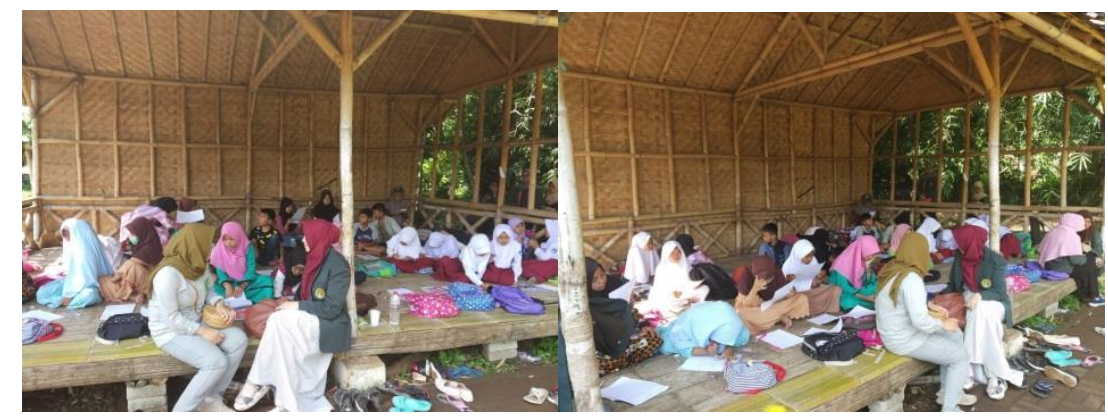

Gambar 3. Kegiatan pelatihan menulis

\section{E. KESIMPULAN}

Berdasarkan hasil pelaksanaan pengabdian pada masyarakat yang telah dilaksankan di Taman Bacaan Masyarakat (TBM) Bening Saguling Foundation yang berlokasi di Jl.SDN Cianjur, Babakan, Cihampelas, maka dapat disimpulkan hal-hal sebagai berikut: 
1. Kegiatan pengabdian pada masyarakat di sekitar Taman Bacaan Masyarakat (TBM) Bening Saguling Foundation ini dapat memberikan manfaat langsung kepada mayarakat dalam meningkatkan pemehaman, keterampilan, dan kesadaran akan pentingnya menjaga lingkungan.

2. Kegiatan pengabdian pada masyarakat ini dapat dijadikan sarana berinovasi dalam usaha mewujudkan lingkungan bersih, sehat, tertib dan lestari khusunya di DAS Citarum.

3. Wahana atau laboratorium bagi para dosen dalam mengimplementasikan teori, pengetahuan, dan keterampilan secara nyata, dan bermanfaat bagi masyarakat luas.

\section{F. UCAPAN TERIMA KASIH}

Terima kasih kepada Direktorat Riset dan Pengabdian Masyarakat, Direktorat Jenderal Penguatan Riset dan Pengembangan Kementerian Riset, Teknologi, dan Pendidikan Tinggi yang telah memberikan kesempatan melalui program pengabdian Kemitraan Masyarakat Stimulus (PKMS) sehingga kegiatan pengabdian ini dapat berjalan dengan lancer dan sesuai harapan.

\section{G. DAFTAR PUSTAKA}

Abbas, Saleh. (2006). Pembelajaran Bahasa Indonesia Yang Efektif Disekolah Dasar. Jakarta: departemen pendidikan nasional dierktorat jendral pendidikan tinggi direktorat ketenagaan.

Ahmad Rofi'uddin dan Darmiyati Zuhdi. (1998/1999). Pendidikan Bahasa dan Sastra Indonesia di Kelas Tinggi. Jakarta: Depdikbud.

Permana, A., \& Widayat, R. (2018). Efektivitas Metode Pembelajaran Latihan Terbimbing Menggunakan Media Berita Dalam Pembelajaran Menulis Naskah Drama (Studi Kuasi Eksperimen pada Mahasiswa STKIP Siliwangi Bandung Tahun Akademik 2013-2014). Parole (Jurnal Pendidikan Bahasa dan Sastra Indonesia), 1(1).

Hariyanto , Suryono (2011) Belajar dan Pembelajaran Teori dan Konsep Dasar . Bandung.

Tarigan. \& Guntur, H. (2008). Menulis sebagai suatu keterampilan berbahasa. Bandung : angkasa. 